\title{
EFEKTIVITAS PENGGUNAAN MEDIA GAMBAR DALAM PEMBELAJARAN IPS TERPADU UNTUK MENINGKATKAN HASIL BELAJAR SISWA DI SMP NEGERI 1 SUNGAI KAKAP KABUPATEN KUBU RAYA
}

\author{
Novita Sariani ${ }^{1}$, Reni Oktaliana ${ }^{2}$ \\ ${ }^{1,2}$ Program Studi Pendidikan Geografi \\ Fakultas Ilmu Pendidikan dan Pengetahuan Sosial IKIP PGRI Pontianak \\ Jalan Ampera Nomor 88 Pontianak - 78116, Telepon (0561) 748219 Fax. (0561) 589855 \\ ${ }^{1}$ Alamat e-mail: novitasariani24@yahoo.co.id
}

\begin{abstract}
Abstrak
Tujuan penelitian untuk mengetahui apakah penggunaan media gambar cetak efektif untuk meningkatkan hasil belajar siswa di SMP Negeri 1 Sungai Kakap Kabupaten Kubu Raya. Tujuan umum penelitian ini adalah meningkatkan tindakan penggunaan media gambar cetak dalam pembelajaran IPS Terpadu untuk meningkatkan hasil belajar siswa di SMP Negeri 1 Sungai Kakap Kabupaten Kubu Raya.Metode penelitian menggunakan metode penelitian tindakan. Bentuk penelitian yang sesuai dengan metode penelitian adalah menggunakan bentuk penelitian tindakan kelas (classroom action research).Teknik pengumpulan data yang digunakan dalam penelitian yaitu teknik observasi partisipatif, teknik wawancara, teknik pengukuran, dan teknik studi dokumentasi. Alat pengumpul data yang digunakan adalah lembar observasi, pedoman wawancara, soal tes, dan dokumentasi. Hasil penelitian diperoleh bahwa setelah dilaksanakan pembelajaran dengan menggunakan media gambar cetak pada siswa kelas VII I di SMP Negeri 1 Sungai Kakap Kabupaten Kubu Raya dalam 2 siklus, dapat disimpulkan bahwa hasil belajar siswa dalam pembelajaran IPS Terpadu dengan menggunakan media gambar cetak siswa mengalami peningkatan.
\end{abstract}

Kata kunci: efektifitas, media gambar, hasil belajar.

\begin{abstract}
The purpose of this research is to know whether the use of printed drawing media is effective to improve student learning outcomes in SMP Negeri 1 Sungai Kakap Kabupaten Kubu Raya. The general objective of this research is to improve the use of printed image media in Integrated IPS learning to improve student learning outcomes in SMP Negeri 1 Sungai Kakap Kabupaten Kubu Raya. The research method using action research method. Form of research in accordance with research methods is to use the form of classroom action research (classroom action research). Data collection techniques used in research are participant observation techniques, interview techniques, measurement techniques, and documentation study techniques. Data collection tools used are observation sheets, interview guides, test questions, and documentation. The result of this research shows that after the learning by using printed drawing media on the students of class VII I in SMP Negeri 1 Sungai Kakap Kubu Raya Regency in 2 cycles, it can be concluded that the learning result of students in IPS learning is integrated using the printed media of the students.
\end{abstract}

Key Word: effectiveness, images media, learning outcomes.

\section{PENDAHULUAN}


Proses belajar mengajar adalah suatu kegiatan yang di dalamnya terjadi proses siswa belajar dan guru mengajar dalam konteks interaktif, dan terjadi interaksi edukatif antara guru dan siswa, sehingga terdapat perubahan dalam diri siswa baik perubahan pada tingkat pengetahuan, pemahaman, dan keterampilan atau sikap.

Setiap putaran melalui empat tahap, yaitu perencanaan, tindakan, pengamatan, dan refleksi". Hal yang peling operasional dalam mewujudkan fungsi adalah meningkatkan hasil belajar siswa. Meningkatkan hasil belajar siswa diperlukan peran guru yang aktif dan kreatif yang dapat membuat pembelajaran IPS Terpadu menjadi lebih baik, menarik dan disukai peserta didik. Suasana kelas perlu direncanakan dan dibangun sedemikian rupa dengan menggunakan metode pembelajaran yang tepat agar siswa dapat memperoleh kesempatan untuk berinteraksi satu sama lain sehingga dapat diperoleh hasil belajar yang optimal.

Media berasal dari bahasa Latin Medium yang secara harfiah yang berarti tengah" "perantara atau pengantar". Dalam bahasa arab media adalah perantara atau pengantar pesan dari pengirim kepada penerima pesan. Dengan menggunakan media gambar cetak dalam mata pelajaran IPS Terpadu hanya meningkatkan hasil belajar siswa dalam proses belajar mengajar dan dapat menimbulkan interaksi antara satu sama lain, dimana pembelajaran adalah tergantung pada interaksi antara satu sama lain, yaitu interaksi antara siswa dengan guru dan siswa dengan siswa, sehingga penggunaan media gambar cetak dapat meningkatkan hasil belajar siswa. Salah satu masalah dalam pembelajaran adalah hasil belajar siswa, metode yang tepat dapat menggunakan media gambar cetak.

Fakta yang ada di lapangan menunjukkan bahwa proses pembelajaran yang sering dilakukan adalah dengan menggunakan metode ceramah, diskusi dan LKS, untuk membantu siswa belajar secara individual dengan lebih efektif dan efisien dengan cara menggunakan alat bantu pengajaran dan media pendidikan menjadikan pekerjaan guru lebih efisien. Penggunaan alat bantu pengajar dan media pendidikan juga berfungsi membantu siswa belajar agar lebih berhasil. Menggunakan media gambar cetak mengandung manfaat untuk keberhasilan 
belajar siswa. Seringkali guru menggunakan ceramah, yaitu hanya menggunakan kata-kata saja. Dengan adanya media gambar cetak siswa tidak hanya mendengarkan kata-kata yng disampaikan guru, tetapi siswa juga dapat melihat gambarnya dengan jelas, mudah untuk diingatnya, dan mudah untuk dipahami, itulah yang menjadikan dasar disarankannya penggunaan media pendidikan dalam proses belajar mengajar.

Masalah yang muncul di kelas VII I yaitu rendahnya hasil belajar siswa dikarenakan guru belum optimal dalam merangsang dan meningkatkan hasil belajar siswa dalam mata pelajaran ilmu pengetahuan sosial sehingga berdampak pada hasil belajar siswa yang rendah, dari hasil yang didapat di lapangan nilai belajar siswa di kelas VII I dapat dikategorikan masih rendah, nilai mata pelajaran IPS Terpadu rata-rata yaitu $65.55 \%$ dari jumlah siswa sebanyak 34 orang yang terdiri 16 laki-laki dan 18 perempuan yang belum mencapai nilai ketuntasan, yang tidak mencapai nilai hasil belajar tuntas jauh dibawah nilai KKM yaitu terdapat 19 orang yang tidak tuntas dalam mata pelajaran IPS Terpadu, sedangkan nilai KKM untuk mata pelajaran IPS Terpadu yaitu 75.

Berdasarkan latar belakang tersebut, penelitian ini mengambil fokus yang berkenaan dengan media yang digunakan oleh guru mata pelajaran IPS Terpadu yaitu Penggunaan Media Gambar Dalam Mata Pelajaran IPS Terpadu Untuk Meningkatkan Hasil Belajar Siswa di SMP Negeri 1 Sungai Kakap Kabupaten Kubu Raya. Dengan harapan penelitian dapat bermanfaat bagi pengembangan kemampuan guru dalam menggunakan media gambar cetak sehingga ada peningkatan hasil belajar siswa.

\section{METODE}

Dalam penelitian ini peneliti menggunakan metode penelitian tindakan Kelas (Action Recearch). Ciri penting dari metode ini adalah memusatkan perhatian pada masalah-masalah yang ada pada saat penelitian dilakukan atau masalah-masalah yang bersifat aktual dan menggambarkan fakta-fakta tentang masalah yang diselidiki sebagai mana adanya (Hadari Nawawi 2012:68). Penelitian tindakan adalah cara suatu kelompok dalam mengorganisasi suatu 
kondisi, dan dimana mereka dapat mempelajari pengalaman mereka, dan membuat pengalaman mereka dapat diakses oleh orang lain. Penelitian tindakan mempunyai tiga keunggulan dibandingkan dengan penelitian menggunakan metode lain. Penelitian tindakan mempunyai beberapa karakteristik, antara lain problem yang dipecahkan merupakan persoalan praktis yang dihadapi peneliti dalam kehidupan profesi sehari-hari. yaitu:

Sarwiji Suwandi (2012:1) mendefinisikan penelitian tindakan kelas (PTK)
"studi yang dilakukan untuk memperbaiki diri sendiri, pengalaman kerja sendiri, tetapi dilaksanakan secara sistematis, terencana, dan dengan sikaap mawas diri. Penelitian tindakan mengacu pada yang dilakukan guru untuk memperbaiki proses pengajaran yang menjadi tanggung jawabnya. Hal penting dalam PTK adalah tindakan nyata yang dilakukan guru untuk memecahkan masalah yang dihadapi dalam proses belajar mengajar".

Supardi (2015: 194) "mengatakan penelitian tindakan kelas (PTK) merupakan penelitian yang menggunakan siklus atau putaran tindakan yang berkelanjutan, maka putaran atau siklusnya minimal dua kali”.

Bentuk penelitian yang digunakan dalam penelitian ini adalah bentuk penelitian tindakan kelas. Suharsimi Arikunto (2010: 135) "Penelitian tindakan kelas (classroom action research), yaitu penelitian yang dilakukan oleh guru di kelas atau di sekolah tempat mengajar dengan penekanan pada penyempurnaan atau peningkatan proses dan praktis pembelajaran”. Pemilihan bentuk penelitian ini didasarkan pada pertimbangan tertentu antara lain disesuaikan dengan masalah, tujuan dan jenis variasi gejala atau ruang lingkup yang hendak diteliti. Penelitian ini dilakukan secara kolaboratif, artinya peneliti melakukan penelitian ini dengan berkolaborasi atau bekerja sama dengan guru IPS Terpadu. Melalui kolaboratif peneliti dan guru secara bersama mengakaji permasalahan yang dihadapi guru dan siswa di kelas.

Subjek dalam penelitian ini adalah guru dan siswa, dimana guru sebagai peneliti yang mengajar mata pelajaran IPS Terpadu di SMP Negeri 1 Sungai Kakap Kabupaten Kubu Raya. Guru sebagai kolaborator yang menerapkan efektivitas penggunaan media gambar cetak dalam mata pelajaran IPS Terpadu di 
kelas VII i dengan siswa yang berjumlah 34 orang, terdiri dari 18 perempuan dan 16 laki-laki di SMP Negeri 1 Sungai Kakap. Adapun data jumlah siswa kelas VII I sebagai berikut :

Tabel 1. Data Jumlah Siswa Kelas VII I

\begin{tabular}{cc}
\hline Jenis Kelamin & Jumlah \\
\hline Laki-laki & 16 \\
\hline Perempuan & 18 \\
\hline Total & 34
\end{tabular}

Sumber : Staf TU SMPN 1 Sungai Kakap Tahun 2015-2016

Peneliti memilih kelas VII I karena berdasarkan hasil praobservasi kelas tersebut adanya masalah yaitu pada hasil belajarnya yang jauh di bawah nilai ketuntasan yaitu 75, maka dari itu peneliti memberikan cara untuk meningkatkan nilai siswa dengan menerapakan efektivitas penggunaan media gambar cetak.

Penelitian tindakan kelas memiliki tahapan atau alur suatu tindakan yang akan dilakukaan didalam suatu ruangan kelas seperti yang digambarkan dalam bagan di atas, adapun tahapan-tahapannya sebagai berikut :

\section{Tahap Perencanaan (Planning)}

Tahap perencanaan atau Planning, merupakan serangkaian rancangan tindakan sistematis untuk meningkatkan apa yang hendak terjadi. Dalam penelitian tindakan, rencana tindakan tersebut harus berorientsi kedepan, maka perencanaan yang dikembangkan harus fleksibel, untuk mengadopsi pengaruh yang tidak dapat dilihat dan rintangan tersembunyi yang mungkin timbul.Perencanaan penelitian tindakan sebaiknya lebih menekankan pada sifatsifat strategis yang mampu menjawab tantangan yang muncul dalam perubahan sosial, dan mengenal rintangan yang sebenarnya. Tahap terpenting yang dilakukan peneliti dan guru sebelum, melakukan penelitian tindakan kelas, kerena dengan perencanaan peneliti akan mengetahui sejauh mana tindakan yang akan dilakukan dapat tercapai pada sebuah tindakan.

Dalam tahapan perencanaan, peneliti dan guru membuat suatu rancangan penelitian yang akan dilakukan melalui penelitian tindakan kelas, yang bertujuan untuk memecahkan masalah yang dihadapi di kelas melalui penerapan efektivitas 
penggunaan media gambar cetak dalam pembelajaran IPS Terpadu untuk meningkatkan hasil belajar siswa di SMP Negeri 1 sungai Kakap Kabupaten Kubu Raya.

Peneliti dan guru yang merupakan pasangan kolaborasi dalam penelitian tindakan kelas, merancang suatu kegiatan perencanaan yang akan dilakukan untuk memecahkan masalah yang dihadapi di kelas. Adapun perencanaan yang dilakukan sebagai berikut :

a. Penelitian bersama guru kolaborasi melakukan diskusi untuk menyusun perangkat pembelajaran. Berdasarkan masalah yang akan ditindak lanjuti, melalui rencana dan analisis kurikulum untuk menentukan standar kompetensi, kompetensi dasar dan indikator yang akan disampaikan pada pelaksanaan penelitian tindakan kelas melalui penerapan efektivitas penggunaan media gambar cetak dalam pembelajaran IPS Terpadu untuk meningkatkan hasil belajar siswa. Kemudian membuat pedoman pelaksanaan dengan menyusun silabus dan rencana pelaksanaan pembelajaran (RPP).

b. Merancang bahan ajar dan menentukan metode dan teknik yang akan digunakan dalam menyampaikan bahan ajar di kelas.

c. Membuat lembar tes dan pengamatan terhadap pelaksanaan tindakan.

d. Mengevaluasi seluruh kegiatan pembelajaran yang telah terlaksana dalam sebuah kelas untuk mengetahui tingkat percapaian tujuan yang diinginkan.

2. Tahap Pelaksana Tindakan (Acting)

Tahap kedua yang harus diperhatikan oleh seorang peneliti adalah act (tindakan) yang terkontrol dan termonitor secara seksama. Tindakan dalam penelitian harus dilakukan dengan hati-hati, dan merupakan kegiatan praktis yang terencana.Tahap tindakan, merupakan penetapan rancangan sekenario efektivitas penggunaan media gambar cetak sebagi implementasi pelaksanaan tindakan kelas. Dalam kegiatan pembelajaran guru harus bersaha ingat dan menaati apa rancangan perlu diperhatikan secara seksama demi mencapai keinginan yang sesuai dengan tujuan semula.

3. Tahap Pengamatan (Observing) 
Pengamatan merupakan kegiatan untuk mengukur sejauh mana efektivitas tindakan telah mencapai sasaran dari tujuan.Pengamatan dilakukan bersama-sama dengan pelaksana tindakan, dimana guru melakukan kegiatan pembelajaran menggunakan efektivitas penggunaan media gambar cetak dan peneliti melakukan pengamatan serta mencatat semua hal yang terjadi dan diperlukan untuk mengetahui seberapa besar keberhasilan pelaksanaan tindakan yang dilakukan.

Sarwiji Suwandi (2012:61) "mengatakan bahwa pengamatan yang peneliti lakukan adalah pengamatan berperan serta secara pasif. Pengamatan itu dilakukan terhadap guru ketika melaksanakan kegiatan belajar mengajar di kelas maupun kinerja siswa selama proses belajar berlangsung".

\section{Tahap Refleksi (Reflecting)}

Refleksi merupakan kegiatan yang dilakukan ketika guru sudah selesai melakukan tindakan. Pada tahap refleksi akan mengkaji secara keseluruhan terhadap tindakan yang telah dilakukan, berdasarkan data yang diperoleh melalui pengamatan akan dievaluasi dan diketahui hasil dari tindakan siklus pertama. Kemudian jika hasil sudah mencapai sasaran atau tujuan, maka tindakan akan dihentikan dan jika hasil yang diperoleh belum mencapai tujuan, maka dilanjutkan dengan melakukan tindakan pada siklus kedua. Dengan memperhatikan kekurangan dan kelebihan dari tindakan siklus pertama untuk dilakukan perbaikan serta penyempurnaan agar tindakan selanjutnya pada siklus kedua dapat mencapai sasaran dan tujuan yang dimaksudkan.

Penelitian tindakan kelas yang dilakukan peneliti, menggunakan model siklus penelitian tindakan kelas (Suharsimi Arikunto, 2008:137).Dalam pelaksaannya memilki empat tahap, yaitu rencana (planning), tindakan (acting), pengamata (observing), dan reflektif (reflecting).Adapun gambaran tahap-tahap menurut model penelitian tindakan kelas sebagai berikut: 


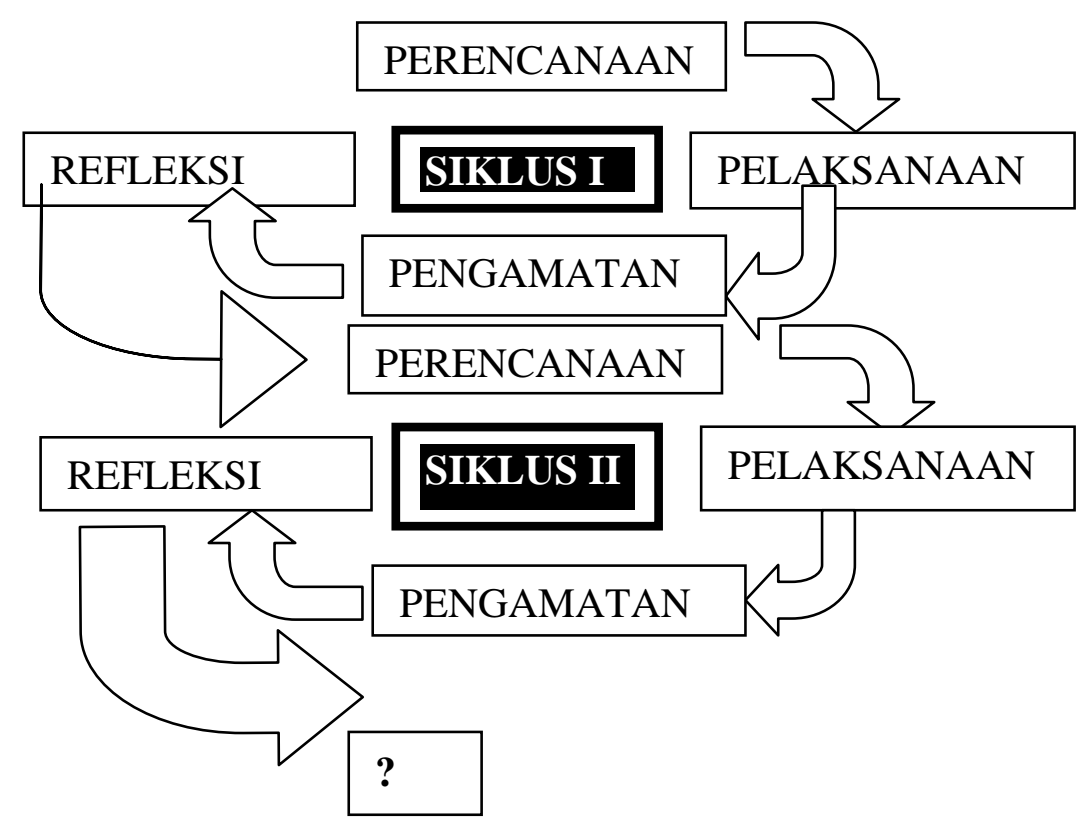

\section{Bagan 1. Model Siklus Penelitian Tindakan Kelas}

(Suharsimi Arikunto, 2008:137)

Mulyasa (2013:71) “mengatakan refleksi menguraikan tentang prosedur analisis terhadap hasil pemantauan dan refleksi tentang prosedur dan dampak tindakan perbaikan yang dilakukan, serta kriteria dan rencana tindakan pada siklus berikutnya". Sarwiji Suwandi (2012:45) "mengatakan bahwa refleksi dalam PTK adalah upaya untuk mengkaji apa yang telah terjadi, apa yang telah dihasilkan atau yang belum berhasil dituntaskan oleh tindak perbaikan yang telah dilakukan. Hasil refleksi itu digunakan untuk menetapkan langkah lebih lanjut dalam upaa mencapai tujuan penelitian tindakan kelas".

\section{HASIL DAN PEMBAHASAN}

Setelah dilaksanakan pembelajaran dengan efektivitas penggunaan media gambar cetak pada kelas VII I di SMP Negeri 1 Sungai Kakap dalam dua siklus, dapat disimpulkan bahwa kemampuan siswa mengalami peningkatan. Penggunaan media gambar cetak yang dilaksanakan dalam dua siklus sedikit demi sedikit menunjukkan peningkatan kemampuan dalam proses pembelajaran IPS Terpadu. Perkembangan ketercapaian indikator dalam rencana pembelajaran. Pembelajaran dengan menggunakan media gambar cetak ditandai dengan diterapkannya aspek 
aspek yang ada dalam pembelajaran. Penggunaan media gambar cetak dalam pembelajaran disesuaikan dengan situasi, kondisi, dan keadaan siswa. Secara umum dalam melaksanakan pembelajaran dengan penggunaan media gambar cetak adalah sebagai berikut:

1. Merencanakan pembelajaran yang akan diterapkan dalam proses belajar mengajar dengan menggunakan media cetak.

2. Menetapkan standar kompetensi dan kompetensi dasar.

3. Menyusun instrument yang akan digunakan untuk penilaian pembelajaran IPS Terpadudengan menggunakan media gambar cetak.

4. Menyiapkan media gambar cetak untuk membantu proses pembelajaran IPS Terpadu.

Hasil penelitian dari siklus I dan siklus II yang diuraikan di atas, ada beberapa implikasi yang perlu dicermati dengan adanya peningkatan hasil belajar siswa kelas VII I di SMP Negeri 1 Sungai Kakap dan peningkatan kerja peneliti dalam pembelajaran baik dalam pengembangan materi, dan penggunaan media. Ada dua hal yang perlu dibahas yaitu: (1) kondisi awal pelaksanaan kegiatan pembelajaran di kelas VII I di SMP Negeri 1 Sungai Kakap, (2) Rincian pelaksanaan penggunan medi gambar cetak. dalam pembelajaran IPS Terpadu untuk meningkatkan hasil beljar siswa pada kelas VII I di SMP Negeri 1 Sungai Kakap yang meliputi: (a) Siklus pertama, (b) Siklus kedua.

\section{Kondisi Awal Kemampuan Siswa dalam Menganalisis Gambar}

Peneliti mewawancarai guru IPS Terpadu kelas VII I tentang pelaksanaan pembelajaran menggunakan media gambar cetak. Pembelajaran di tingkat SMP telah menggunakan kurikulum tingkat satuan pendidikan (KTSP), dalam pembelajaran menggunakan media gambar cetak di kelas VII I mengacu pada kompetensi dasar yang dijabarkan dalam silabus. Pembelajaran IPS Terpadu terdiri atas pembelajaran keterampilan mendengarkan (menyimak), keterampilan berbicara. Pembelajaran IPS Terpadu khususnya berbicara secara umum yang selama ini diamati di lingkungan tempat kerja kurang optimal. Baik dari segi dalam penyajian materi, maupun media pembelajaran dan metode ceramah. 
Metode ceramah tetap mendominasi pelaksanaan pembelajaran. Hal ini terjadi karena rata-rata atau sebagian besar guru kurang memahami dan menguasai materi dan merasa kesulitan dalam menyajikannya.

Jalannya proses pembelajaran di kelas VII ISekolah Menengah Pertama Negeri 1 Sungai Kakap yang dialami, khususnya pada mata pelajaran IPS Terpadu kompetensi dasar pelajaran IPS Terpadi ditemukan beberapa kondisi yang menyebabkan rendahnya kemampuan siswa dan hasil belajar siswa dalam menguasai materi. Kondisi ini antara lain:

a. Kurangnya sumber belajar, misalnya: buku rujukan, media pandang dengar, kondisi ini mengakibatkan kurangnya pengetahuan dan wawasan guru dalam menyajikan materi.

b. Adanya siswa yang mempunyai sifat sangat pendiam, atau sebaliknya hal ini sangatlah menyulitkan dalam proses pembelajaran, sehingga berpengaruh pada siswa yang lain serta berpengaruh terhadap kurang berhasilnya dalam kegiatan pembelajaran.

c. Guru tidak menggunakan media dalam proses pemebalajaran yang membuat siswa tidak aktif, kreatif, dan menyenangkan.

Berangkat dari semua yang diuraikan di atas, maka perlu diupayakan inovasi pembelajaran untuk mengoptimalkan kegiatan siswa, sehingga mereka bersemangat untuk maju. Dengan pembelajaran yang inovatif akan dapat menumbuhkan minat dan potensi dalam kegiatan pembelajaran. Pembelajaran yang inovatif akan membuat pembelajaran berjalan aktif, produktif, dan tercipta suasana belajar penuh gairah, pembelajaran yang bermakna bagi siswa dan meningkatknya hasil belajar siswa dan kinerja guru.

Kemampuan menggunakan media gambar cetak di kelas VII I Sekolah Menengah Pertama Negeri 1 Sungai Kakap sebelum diterapkan penggunaan media gambar cetak hasil belajar siswa masih sangat rendah. Karena disamping faktor pengetahuan yang dimiliki siswa hanya bersifat teoritis bukan praktis. Maka harus diupayakan memadukan antara pengetahuan dengan pengalaman siswa dalam kehidupan sehari-hari atau dalam kehidupan nyata. Dengan 
memadukan antara pengetahuan secara teoritis dan pengetahuan secara praktis diharapkan siswa mampu meningkatkan hasil belajar siswa.

Selama melaksanakan proses pembelajaran hingga akhir tindakan dengan penggunaan media gambar cetak. Dapat dilihat tingkat keberhasilan siswa dalam pembelajaran IPS Terpadu. Tingkat kemampuan siswa dalam menganalisis sebuh gambar dipengaruhi oleh beberapa hal, antara lain: kejelasan gambar, kejelasan guru saat menyampikan materi atau arah dalam proses pembelajaran. Untuk mengatasi hal tersebut guru harus kreatif dan inovatif, untuk menumbuhkan minat siswa, banyak memberikan latihan, menyediakan buku-buku pantun, media pembelajaran, dan menumbuhkan semangat siswa.

\section{Rincian Pelaksanaan Penggunaan Media Gambar Cetak}

Berdasarkan kenyataan masih rendahnya hasil belajar siswa dalam pembelajaran IPS Terpadu yang dipengaruhi oleh beberapa kondisi yang tidak menguntungkandi sekolah, maka dalam penelitian ini akan mengupayakan dan berusahamengatasi permasalahan. Penelitian tindakan kelas (PTK) dipilih untuk mengatasi permasalahan tersebut. PTK ini merupakan kolaborasi antara peneliti dengan kolabor, dan siswa kelas VII I di SMP Negeri 1 Sungai Kakap yang memiliki perspektif yang berbeda. Bagi siswa untuk meningkatkan keberhasilan pembelajaran IPS Terpadu yang akan berpengaruh terhadap meningkatnya prestasi siswa, dan bagi peneliti untuk mengetahui dan membuktikan apakah benar penggunaan media gambar cetak dapat meningkatkan hasil belajar siswa dalam pembeljaran IPS Terpadu. Pembelajaran dengan penggunaan media gambar cetak dalam PTK untuk meningkatkan hasil belajar siswa kelas VII I di SMP Negeri 1 Sungai Kakap ini dilaksanakan dalam dua siklus. Dalam setiap siklusnya ada empat tahap perlakuan, yaitu:
a. Perencanaan
b. Tindakan
c. Pengamatan
d. Refleksi 
Dalam setiap siklus keberhasilan dan ketidakberhasilan guru dalam mengatasi masalah, ketidakberhasilan diperbaiki pada siklus berikutnya. Hasil pembelajaran setiap siklus harus menunjukkan perubahan perbaikan. Dari beberapa indikator yang dirumuskan dalam rencana pembelajaran pada siklus pertama, dan siklus kedua, dapat diketahui terjadi peningkatan keberhasilan siswa dalam setiap sikusnya. Berikut ini uraian tentang peningkatan kemampuan dalm penggunaan medi gambar certak dalam pembelajaran IPS Terpadu setiap siklusnya.

\section{Ketercapaian Peningkatan Keberhasilan Siswa pada Siklus Pertama}

Kemampuan yang dapat dicapai siswa pada siklus pertama adalah pengetahuan tentang pembelajaran IPS Terpadu, peningkatan kemampuan ini tidak berarti tanpa ada kesalahan, tetapi tingkat kesalahan pada waktu menggunakn media gambar cetak hanyalah sedikit. Sedangkan indikator yang lain yaitu agar siswa mampu berpikir sendiri atau berpikir mandiri dan mampu mengungkapkan gagasannya.

Dengan adanya pembelajaran seperti yang diterapkan, peneliti menemukan bahwa siswa yang mempunyai hasil rendah ikut tertarik dan mempunyai keberanian untuk berbicara dan mengungkapkan gagasannya walaupun kadangkadang jawaban tersebut salah akan tetapi pola pembelajaran yang ditetapkan oleh peneliti mampu menumbuhkan semangat belajar yang tinggi juga mampu meningkatkan hasil dan perhatian siswa terhadap pelajaran.

Pada akhir siklus diadakan penilaian. Kriteria penilaian keberhasilan siswa dalam pembelajaran IPS Terpadu dengan menggunakan media gambar cetak melakukan kesesuian isi dengan tema,ketepatan materi dengan gambar yang akan digunakan. Berikut penjelasan keberhasilan siswa dalam pembelajaran IPS Terpadu tiap siklus:

a. Rata- rata nilai yang diperoleh siswa pada akhir siklus I:

Jumlah seluruh nilai siswa : Jumlah siswa $=2376: 34=69,88$

b. Rata- rata nilai yang diperoleh siswa pada akhir siklus II:

Jumlah seluruh nilai siswa : Jumlah siswa $=2560: 34=75,29$ 
c. Ketercapaian peningkatan siswa pada siklus kedua $=13 \%$

Setelah diadakan bimbingan secara intensif cara menggunakan media gambar cetak dalam pembelajaran IPS Terpadu ada perubahan yang cukup signifikan. penggunaan media gambar cetak dalam pembelajaran IPS Terpadu Penerapan dapat meningkatkan hasil belajar siswa. Faktor-faktor pendukung yang dapat meningkatkan keberhasilan belajar siswa adalah diterapkannya enam komponen yang berperan sangat besar adalah komponen pemodelan.

\section{SIMPULAN}

Berdasarkan hasil penelitian dan analisis data, maka dapat disimpulkan bahwa Kesimpulan, secara umum peningkatan dalam penelitian adalah peningkatan hasil belajar siswa dalam pembelajaran IPS Terpadu dengan menggunakan media gambar cetak pada siswa kelas VII I di SMP Negeri 1 Sungai Kakap Kabupaten Kubu Raya mengalami peningkatan dimana seluruh nilai siswa mencapai ketuntasan. Secara khusus 1) Dalam penggunaan media gambar cetak dalam pembelajaran IPS Terpadu pada siswa kelas VII I SMP Negeri 1 Sungai Kakap sudah mengalami peningkatan dari pra tindakan, siklus I dan siklus II dalam hal menganalisis sebuah gambar, dan mencocokkan gambar yang sesuai dengan pertanyaan (menjodohkan). 2) Pada pra tindakan hasil belajar siswa pada mata pelajaran IPS Terpadu yaitu 62,79, dan pada siklus I hasil belajar siswa mulai mengalami peningkatan yaitu 69,88, sedangkan pada siklus II hasil belajar siswa yaitu 75, 29 pada siklus II disini hasil belajar siswa sudah berhasil mencapai ketuntatasan. Hal tersebut sangat membantu siswa dalam pencapaian nilai KKM yaitu $75 \%$. 3) Perkembangan siswa dalam penggunaan media gambar cetak dalam pembelajaran IPS Terpadu meningkat dan tuntas sebanyak 100\% dari jumlah siswa sebanyak 34 orang siswa. Penggunaan media gambar cetak dapat meningkatkan hasil belajar siswa, dari hasil belajar siswa yang rendah dengan menggunakan media gambar cetak hasil belajar siswa meningkat.

\section{DAFTAR PUSTAKA}

Anitah, Sri. (2012). Media Pembelajaran. Surakarta : Yuma Pustaka. 
Anwar Kasful \& Harmi Hendra. (2011). Perencanaan Sistem Pembelajaran. Bandung: Alfabeta.

Arikunto, Suharsimi., Suhardjono., \& Supardi. (2015). Penelitian Tindakan Kelas. Jakarta: Bumi Aksara.

Cipta.

Arsyad, Azhar. (2014). Media Pembelajaran. Jakarta: Rajawali Press.

Burhan, (2013). Penelitian Tindakan Kelas. Yogyakarta: Araska.

Darmadi, Hamid. (2011). Metode Penelitian Pendidikan. Bandung: Alfabeta.

Dantes. (2012). Metode Penelitian. Yogyakarta: C.V Andi.

Hamalik, Oemar. (2013). Kurikulum dan Pembelajaran. Jakarta: Bumi Aksara. (2015). Proses Belajar Mengajar. Jakarta: Bumi Aksara.

Ismawati, Esti. (2011). Metode Penelitian Pendidikan Bahasa dan Sastra. Surakarta: Yuma Pustaka.

Kunandar. (2013). Langkah-langkah Penelitian Tindakan Kelas Sebagai Pengembangan Profesi Guru. Jakarta: Rajawali Press.

Mulyasa, E. (2013). Praktik Penelitian Tindakan Kelas. Bandung: PT. Remaja Rosdakarya.

Nawawi, Hadari. (2012). Metode Penelitian Bidang Sosial. Jakarta: Gajah mada Univsesity Press.

(2012). Metode Penelitian Bidang Sosial. Jakarta: Gajah mada University Press.

Rusman, (2013). Model-Model Pembelajaran. Jakarta: PT Rajagrafindo Persada.

Sadiman, S Arief., Rahardjo, R., Haryono, Anung., \& Harjito. (2014). Media Pendidikan. Jakarta: Rajawali Press.

Sudjana, Nana. (2014). Penilaian Hasil Proses Belajar Mengajar. Bandung: PT Remaja Rosdakarya.

Sugiyono.(2013). Metode Penelitian Pendidikan. Bandung: Alfabeta. 
( 2012). Statistika untuk Penelitian. Bandung: Alfabeta.

Sukardi, (2012). Evaluasi Pendidikan. Jakarta: Bumi Aksara.

Sukiman.(2012). Pengembangan Sistem Evaluasi. Yogyakarta: Insan Madani.

Suryabrata,Sumadi. (2015). Metodologi Penelitian. Jakarta: Rajawali Press.

Suwandi, Sarwiji. (2012). Penelitian Tindakan Kelas (PTK) dan Penulisan Karya Ilmiah. Surakarta: Yuma Pustaka.

Tim Penyusun. (2014). Pedoman Penyusunan Skripsi Bagi Mahasiswa, Pontianak : IKIP-PGRI Pontianak. 